\title{
Keberadaan Kelompok Minoritas: Mitos Homogenitas Bangsa Jepang
}

\author{
Arsi Widiandari \\ Program Studi S1 Bahasa dan Kebudayaan Jepang, Universitas Diponegoro \\ Email: arsi@lecturer.undip.ac.id
}

\begin{abstract}
Abstrak
Fokus penelitian ini adalah untuk membahas tentang keberadaan kelompok minoritas yang berada di Jepang. Eksistensi kelompok minoritas tersebut mematahkan pemahaman tentang bangsa Jepang yang terdiri dari masyarakat yang homogen. Penelitian ini menggunakan metode kepustakaan, yaitu dengan mengambil data dari berbagai literatur seperti artikel ilmiah, buku referensi serta laporan resmi yang dikeluarkan oleh Pemerintah Jepang melalui website kementerian terkait. Dari data yang ditemukan terkait tentang eksistensi kelompok minoritas tersebut, dapat disimpulkan bahwa eksistensi kelompok minoritas seperti Zainichi Korea, Burakumin, Ainu dan sejumlah tenaga migran merupakan bukti bahwa Jepang bukanlah bangsa yang homogen, melainkan merupakan bangsa yang multikultur. Tulisan ini diharapkan dapat melengkapi penelitian yang telah dilakukan sebelumnya terkait identitas bangsa Jepang.
\end{abstract}

Kata Kunci: Homogenitas; Kelompok Minoritas; Masyarakat Jepang

\begin{abstract}
The focus of this research is to discus the existence of minority groups in Japan. The existence of this minority community breaks the understanding of the Japanese nation which consists of a homogeneous society. This study uses the library method, by taking data from various literatures such as scientific articles, reference books and official reports issued by the Japanese Government through official website. This study found that existence of minority community in Japan for example Zainichi Korea, Burakumin groups, Ainu and a number of migrant workers is proof that Japan is not a homogeneous society but is a multicultural society. This paper is expected to complement the research that has been done previously related to the identity of the Japanese nation.
\end{abstract}

Keywords: Homogeneous; Japanese society; Minority group

\section{Latar Belakang}

Saat ini, arus perpindahan manusia dari satu tempat ke tempat lainnya merupakan sesuatu yang tidak dapat dihindari. Migrasi manusia dapat terjadi dalam kelompok kecil maupun individu. Hal ini tidak dapat dihindari, karena berkaitan dengan faktor globalisasi di mana, globalisasi menghilangkan hambatan seseorang dalam melakukan migrasi.

Masuknya orang asing ke Jepang tentunya menjadi topik yang menarik untuk dibahas hingga saat ini, mengingat Jepang pernah menerapkan politik isolasi negara ( Sakoku ) selama kurang lebih 200 tahun, hingga akhirnya membuka kembali negara tersebut yang ditandai dengan Restorasi Meiji pada tahun 1868 .

Apabila kita melihat Jepang saat ini, maka kita akan menemukan Jepang yang semakin multikultural, hal tersebut ditandai dengan semakin banyaknya akses dan kemudahan orang asing untuk masuk dan menetap di Jepang. Di sisi lain, Jepang pernah menyatakan dirinya sebagai negara dengan bangsa yang homogen. Hal tersebut tertuang dalam pernyataan yang dikeluarkan oleh PM Nakasone Yasuhiro pada tahun 1986 yang menyatakan bahwa "Japan is a homogeneous natural community", atau Jepang sebagai 
komunitas yang homogen (Denoon, 2001: 1).

Meskipun Jepang yang modern seperti saat ini merupakan bangsa yang terdiri dari masyarakat yang majemuk, namun kita perlu mengetahui kapan sesungguhnya kemunculan ideologi homogenitas Jepang, latar belakang yang mendasarinya serta bagaimana proses perubahan hingga Jepang dapat menjadi bangsa yang multikultur. Beberapa penelitian terkait hal ini pun telah dilakukan oleh beberapa peneliti sebelumnya.

Edi Hariyadi dalam artikel ilmiah yang berjudul Homogenitas versus Multikulturalisme : Perdebatan Penerimaan Pekerja Asing di Jepang (2012), mengungkapkan bahwa adanya pertentangan antara konsepsi homogenitas dengan multikulturalisme di tengah masuknya tenaga kerja asing ke Jepang untuk mengisi sektor-sektor pekerjaan yang ada di Jepang. Hariyadi menerangkan bahwa pemahaman multikulturalisme dibutuhkan untuk membuat masyarakat Jepang menerima pekerja asing dengan berbagai macam latar belakang budaya dan agama.

Penelitian selanjutnya datang dari skripsi yang ditulis oleh Alvi Aniqo Nuri Salsabila (2021) yang berjudul Identitas Biracial Jepang dalam Film Hafu. Pada penelitiannya tersebut, Alvi mengangkat isu tentang masyarakat Jepang yang homogen dan keberadaan sejumlah anak hasil pernikahan internasional (antara orang Jepang dengan orang asing) dalam film yang berjudul Hafu. Film tersebut memberikan gambaran bahwa di tengah kondisi Jepang yang kini semakin terbuka terhadap bangsa asing membuka kesempatan lahirnya pernikahan internasional. Hal ini tentu akan memberikan perubahan untuk Jepang di masa mendatang untuk menjadi negara yang semakin multicultural.
Penelitian kali ini lebih berfokus tentang keberadaan kelompok minoritas di Jepang yang mematahkan konsepsi Jepang sebagai bangsa yang homogen. Selain itu penelitian kali ini diharapkan dapat memberikan tambahan informasi dari penelitian yang sebelumnya telah dilakukan terkait Jepang yang homogen.

\section{Metodologi Penelitian}

Metode penelitian yang digunakan dalam penelitian ini adalah studi kepustakaan. Menurut Sugiyono (2012: 291) bahwa studi kepustakaan berkaitan dengan kajian teoritis dan referensi lain yang berkaitan dengan nilai, budaya, dan norma yang berkembang pada situasi sosial yang diteliti, selain itu studi kepustakaan sangat penting dalam melakukan penelitian, hal ini dikarenakan penelitian tidak akan terlepas dari literatur ilmiah. Sehingga dapat dikatakan bahwa studi kepustakaan merupakan sebuah studi yang mengutamakan literatur atau referensi tertulis sebagai bahan utama untuk mengaitkan rumusan permasalahan.

Hal-hal yang dilakukan oleh penulis dalam Menyusun artikel ilmiah ini di antaranya dengan mengambil beberapa data dan bahan kajian dari sumber literatur seperti buku referensi, artikel ilmiah, cuplikan berita di media masa online dan lain-lain. Penggunaan sumber data yang berasal dari media masa online resmi dirasa merupakan sumber yang cukup valid dan terpercaya untuk dapat digunakan pada penelitian ini.

Penelitian ini kemudian dilakukan dengan membagi menjadi beberapa tahap penelitian, yaitu pada tahap awal penulis akan melakukan observasi terkait konsep Jepang yang homogen. Observasi ini sangat penting karena menjadi landasan dalam topik utama dalam penelitian ini. Setelah mendapatkan data primer terkait konsep homogenitas bangsa Jepang, maka 
yang dilakukan selanjutnya adalah mendapatkan data terkait kelompok minoritas di Jepang. Data tersebut yang kemudian akan digunakan untuk membuat analisa untuk menjawab permasalahan utama terkait mitos homogenitas bangsa Jepang.

\section{Pembahasan}

Seperti yang telah disampaikan sebelumnya pada latar belakang, masyarakat Jepang sering digambarkan sebagai masyarakat yang homogen. Isu homogenitas Jepang tidak pernah lepas dari adanya konsep Nihonjinron. Secara harfiah, Nihonjinron dapat diartikan sebagai teori tentang orang Jepang. Berbicara tentang Nihonjinron, berarti berbicara tentang ras, geografi dan Bahasa. Teori Nihonjinron sering dikaitkan dengan identitas bangsa Jepang dan nasionalisme Jepang. Nihonjinron sering kali menyinggung tentang keistimewaan dan keunikan bangsa Jepang yang tidak ditemukan oleh bangsa-bangsa lainnya. Mouer dan Sugimoto (1986: 406) dalam Burgess, Chris, mengatakan bahwa Nihonjinron memiliki dua paham utama, yaitu:

(a) bahwa masyarakat Jepang memiliki 'keunikan' yang unik dan

(b) Orientasi masyarakat Jepang adalah pada kelompok.

Orientasi kelompok ini kemudian menjadi pola kebudayaan dominan yang membentuk perilaku orang Jepang. Premis utama Nihonjinron adalah bahwa masyarakat Jepang adalah masyarakat yang homogen (tan'itsu minzoku), yang membentuk sebuah bangsa yang secara ras sama (tan'itsu minzoku kokka).

Identitas mengenai bangsa Jepang banyak diangkat dalam literatur Nihonjinron. Secara harfiah, Nihonjinron sendiri memiliki arti teori tentang manusia Jepang, dalam arti yang lebih luas Nihonjinron memiliki makna sebagai sebuah identitas nasional yang terkait juga tentang kebudayaan bangsa Jepang. Dalam artikel yang berjudul Japanese Cultural Identity, (1993 : 94) Manabe Kazufumi dan Harumi Befu mengelompokkan Nihonjinron ke dalam empat kategori, di antaranya :

1. Homogenitas :

2. Darah

3. Kompetensi Budaya

4. Partisipasi Sosial

Masyarakat Jepang sering digambarkan sebagai masyarakat yang homogen, imej tersebut tentunya tidak muncul begitu saja. Latar belakang sejarah yang panjang kemudian yang didukung oleh pernyataan beberapa pejabat pemerintahan Jepang memberikan gambaran bahwa bangsa yang juga akrab disebut sebagai negara matahari terbit tersebut, merupakan bangsa yang homogen. Politik Sakoku atau menutup negara yang dijalankan oleh pemerintahan Tokugawa selama kurang lebih dua ratus tahun, disinyalir merupakan masa yang paling penting dalam membentuk masyarakat yang homogen. Pada periode Sakoku ini pula, banyak kebudayaan khas Jepang yang lahir sehingga dikatakan bahwa masyarakat Jepang membentuk jati dirinya selama pelaksanaan politik Sakoku.

\subsection{Masyarakat Jepang yang Majemuk}

Jepang memiliki reputasi sebagai bangsa yang homogen, dengan masyarakat yang harmonis, terdiri dari ras yang sama dan tidak banyak perbedaan dari sisi bahasa (linguistik). Akan tetapi, anggapan Jepang sebagai bangsa yang homogen ternyata tidak selamanya dapat dipertahankan. Beberapa peneliti mengangkat tema kemajemukan Jepang untuk membantah mitos homogenitas Jepang. Isu mengenai kemajemukan Jepang mulai muncul sejak 
tahun 1990an saat Jepang secara besarbesaran menggunakan pekerja asing dalam sektor industri kelas berat.

Pada tahun 1960an, Jepang mengalami puncak perekonomian sehingga pada masa itu industri Jepang menguasai dunia dan produknya digunakan oleh seluruh masyarakat dunia. Nama-nama besar seperti SONY, MITSUBISHI pun akrab bagi masyarakat dunia. Pada masa perkembangan ekonomi ini, banyak penduduk Jepang yang beralih dari petani ke pekerja industri manufakturing. Akan tetapi, setelah tahun 1990, saat Jepang mengalami resesi ekonomi banyak perusahaan yang mengubah sistem perekrutan pekerja, salah satunya adalah dengan mempekerjakan sejumlah pekerja asing. Banyak dari pekerja asing tersebut datang dari wilayah Asia Tenggara dan juga Brazil. Mereka turut berperan dengan kemajuan industri Jepang. Dengan adanya isu sejumlah pekerja asing yang menguasai industri Jepang, secara tidak langsung mengangkat isu Jepang sebagai negara yang multietnis.

Yoshio Sugimoto dalam bukunya yang berjudul "An Introduction to Japanese Society 2nd Edition" (2003 :185) menyebutkan mengenai sejumlah golongan minoritas yang dianggap memiliki tempat di tengah masyarakat Jepang namun keberadaannya tak jarang mendapatkan diskriminasi bahkan oleh masyarakat Jepang sendiri.

\begin{tabular}{|l|l|l|l|}
\hline \multicolumn{1}{|c|}{ Grup } & $\begin{array}{c}\text { Popula } \\
\text { si }\end{array}$ & $\begin{array}{l}\text { Konsentr } \\
\text { asi } \\
\text { Geografi }\end{array}$ & $\begin{array}{c}\text { Latar } \\
\text { Belakang } \\
\text { Minorita } \\
\text { s }\end{array}$ \\
\hline $\begin{array}{l}\text { Buraku } \\
\text { min }\end{array}$ & $\begin{array}{l}2.000 .0 \\
00\end{array}$ & Kansai & $\begin{array}{l}\text { Sistem } \\
\text { kasta } \\
\text { pada } \\
\text { zaman } \\
\text { feodal }\end{array}$ \\
\hline $\begin{array}{l}\text { Zainchi } \\
\text { Korea }\end{array}$ & $\begin{array}{l}600.00 \\
0\end{array}$ & Kansai & $\begin{array}{l}\text { Koloniali } \\
\text { sasi }\end{array}$ \\
\hline
\end{tabular}

\begin{tabular}{|l|l|l|l|}
\hline & & & $\begin{array}{l}\text { Jepang } \\
\text { terhadap } \\
\text { Korea }\end{array}$ \\
\hline Ainu & 24000 & Hokkaido & $\begin{array}{l}\text { Agresi } \\
\text { penduduk } \\
\text { Honshu } \\
\text { ke Jepang } \\
\text { Utara }\end{array}$ \\
\hline $\begin{array}{l}\text { Pekerja } \\
\text { Asing }\end{array}$ & 1.300 .0 & $\begin{array}{l}\text { Tersebar } \\
\text { di seluruh } \\
\text { Jepang }\end{array}$ & $\begin{array}{l}\text { Kebutuha } \\
\text { n tenaga } \\
\text { kerja non- } \\
\text { profesion } \\
\text { al }\end{array}$ \\
\hline
\end{tabular}

Dengan melihat kolom di atas, dapat kita lihat pembagian kelompok minoritas di Jepang beserta konsentrasi geografi dan latar belakang yang menjadikan mereka dianggap sebagai kelompok minoritas. Berdasarkan data di atas, populasi paling banyak diduduki oleh kaum Burakumin, pekerja asing, Zanichi Korea dan masyarakat suku Ainu.

\subsubsection{Burakumin}

Kata Buraku mencerminkan sebuah kota atau tempat suatu komunitas, sehingga Burakumin dapat diartikan sebagai orang yang menetap di daerah Buraku. Pada zaman Tokugawa diberlakukan sistem Shinokosho atau pelapisan sosial berdasarkan kasta. Shi=bushi atau kaum samurai, No=nomin atau petani, Ko=Kosonin atau pengrajin dan Sho=Shomin atau pedagang. Di luar kasta tersebut terdapat pula kasta-kasta lain seperti Eta dan Hinin yang merupakan kasta paling rendah atau setara dengan kaum paria/budak. Burakumin telah menjadi perdebatan yang hebat dalam masyarakat Jepang saat ini, sebagian meyakini mereka adalah keturunan masyarakat Korea yang tinggal di Jepang sedangkan sebagian lainnya meyakini mereka adalah keturunan kasta Eta.

Pada saat pemerintahan Meiji, sistem kasta yang semula diberlakukan 
bagi masyarakat Jepang selama era Tokugawa dihapuskan. Namun, meski sistem kasta tersebut telah dihapuskan, kaum burakumin tetap mendapatkan diskriminasi. Hal ini dikarenakan identitas seseorang yang terikat dengan koseki mereka. Dalam bidang pendidikan, pemerintah Meiji terlalu lamban dalam mengembangkan sekolah dan transportasi juga komunikasi di daerah perkampungan Burakumin. Konsekuensinya, mereka mendapatkan pendidikan yang rendah dan seringkali ditempatkan di sektor pekerjaan upah rendah.

Dalam sebuah artikel yang ditulis di harian surat kabar BBC, diketahui bahwa pada tahun 1993 pemerintah membuat sebuah survey terkait komunitas atau organisasi yang tersebar di seluruh Jepang. Diketahui bahwa dalam sebuah organisasi yang bernama BLL ( The Burakumin Liberal League ) yang dibentuk pada tahun 1955 menyebutkan bahwa total burakumin mencapai tiga juta jiwa di seluruh Jepang.

\subsubsection{Zainichi Korea}

Sesudah PD II, banyak orang Korea dan Burakumin yang bertahan hidup dan mencari keberuntungan, yang paling signifikan adalah dampak dari kekalahan Korea dan berkembang pesatnya ekonomi Jepang, membujuk orang Korea untuk mempertaruhkan masa depan mereka di Jepang. Sampai tahun 1965, status orang Korea di Jepang masih ambigu. Meskipun mereka dianggap warga negara Jepang pada masa kolonial, tetapi kewarganegaraan mereka dilucuti setelah berakhirnya PD II. Pada tahun 1952, pemerintah memutuskan untuk mengawasi dan mendaftar orang asing. Kesimpulan dari perjanjian perdamaian tahun 1965, kewarganegaraan Korea Selatan dipaksakan kepada orang Korea di Jepang.

Pada masa sesudah perang, orang Korea di Jepang mengalami berbagai macam diskriminasi. Karena status mereka sebagai orang asing, banyak dari mereka yang tidak memenuhi syarat untuk bekerja di pemerintahan. Sebagian dari mereka membuka usaha manufaktur kecil, tempat makan, pachinko dan pekerjaan di sektor sekunder.

Saat ini, perubahan telah terjadi seiring dengan serangkaian perjuangan orang Korea dalam bidang hukum dan keadilan. Pada tahun 1970, lebih dari tiga perempat orang Korea adalah kelahiran Jepang dan bersekolah di Jepang. Dan pada tahun 1985, 70\% dari perkawinan orang Korea adalah dengan orang Jepang. Nama Korea-Jepang telah banyak ditemukan dibidang-bidang bergensi seperti Son Masayoshi yang merupakan CEO Softbank Mobile Phone, salah satu perusahaan profider telekomunikasi terbesar di Jepang.

\subsubsection{Ainu}

Orang Ainu ( berasal dari kata aynu, yang mempunyai arti orang yang tinggal di Ainu ), bermukim di bagian utara pulau Honshu, Hokkaido, Sakhalin dan Kurile sejak awal pencatatan sejarah Jepang. Suku Ainu sesungguhnya adalah kelompok nelayan dan pedagang dengan cangkupan wilayah ke kepulauan Aleutian ke timur, Rusia dan China ke barat, dan Shamo (sebutan Ainu untuk orang Jepang) ke selatan.

Pada pemerintahan Tokugawa, sebutan untuk Ainu Mosir ( pemukiman Ainu ) adalah Ezoto / Ezochi. Eksploitasi dan diskriminasi terhadap orang Ainu telah terjadi sejak abad 19, khususnya antara orang Ainu dengan Matsumae-han. Untuk mempertahankan diri, orang Ainu berperang melawan orang Jepang sehingga pecahlah beberapa pertempuran diantaranya pertempuran Sakshain pada 1669 dan pertempuran Kunashiri-Menashi pada 1789. Ainu mengalami kekalahan sehingga suku ini kemudian sepenuhnya 
berada dibawah jajahan Jepang hingga Meiji.

Pertikaian ini bukanlah lagi mengenai masalah etnis, melainkan sudah menjadi masalah politik. Shamo-jin ( sebutan orang Ainu kepada orang Jepang ) berusaha menguasai Ezochi, sehingga perekonomian Ainu sangat bergantung pada Matsumae-han. Orang Jepang juga mengggunakan orang Ainu sebagai pekerja paksa. Yang menarik, para intelektual Tokugawa mempertimbangkan untuk menjajah Ainu dengan menggunakan orang-orang Burakumin.

Pada tahun 1869 pemerintah Meiji mengubah Ezochi menjadi Hokkaido dan mendeklarasikannya sebagai tanah kekaisaran pada tahun 1873. Sejak tahun tersebut, jumlah orang Jepang yang tinggal di Hokkaido mencapai 168.000 dan pada tahun 1897 meningkat menjadi 786.000 orang. Mereka umumnya adalah adalah para bekas samurai pada zaman Tokugawa, pada tahun 1880an yang bermaksud untuk mengeksploitasi alam Hokkaido khususnya hasil alam berupa ikan salmon dan rusa.

Keberadaan Ainu nyaris punah dengan diberlakukannya politik asimilasi yang memaksa orang-orang Ainu tidak bisa lagi mengikuti budaya dan tradisinya. Mereka dipaksa mengadopsi nama Jepang dan dicatat dalam Koseki. Puncaknya adalah dengan dibentuknya Hokkaido Aborigine Protection Act pada tahun 1899, walaupun mengaku bertujuan melindungi orang Ainu badan legislasi tersebut justru menghancurkan jalan hidup dan tradisi orang Ainu. Tujuan dari legislasi tersebut tak lain adalah untuk mengubah orang Ainu menjadi bangsa petani dan mengasimilasi mereka menjadi orang Jepang, sehingga mereka dilarang untuk mencari ikan, berburu dan menebang pohon dan diharuskan menggunakan bahasa nasional.

Proses asimilasi ironisnya menimbulkan perbedaan etnisitas di Hokkaido. Pada pertambangan yang terdapat di Hokkaido tidak hanya merusak ekosistem alam, namun juga turut mempekerjakan orang dari luar Jepang. Pada tahun 1944, lebih dari 60 persen pekerja tambang di Hokkaido adalah orang Korea yang juga memicu pernikahan campuran antara Korea dengan Ainu.

Kayano Shigeru, seorang pemahat sekaligus politisi mengatakan:

“ kami bukanlah keturunan aborigin. Kami adalah bangsa yang tinggal di Hokkaido, sebuah daratan yang dikenal dengan Ainu Mosir yang berarti negeri yang damai untuk manusia. Orang-orang Jepang menyerbu dan merampas tanah kami. Sehingga tak diragukan lagi, Ainu Mosir adalah tanah untuk bangsa Ainu”.

\subsubsection{Masuknya Pekerja Asing}

Jepang tengah memasuki situasi yang cukup serius terkait permasalahan demografi. Angka kelahiran yang terus mengalami penurunan, diiringi meningkatnya populasi lansia, dengan kondisi demikian Jepang tentunya menghadapi permasalahan lainnya yakni berkurangnya populasi usia produktif yang merupakan ketersediaan tenaga kerja. Dengan demikian pemerintah Jepang mencari alternatif untuk menyelesaikan krisis ketersediaan tenaga kerja salah satunya dengan membuka peluang bagi tenaga kerja asing untuk masuk ke Jepang. Ministry of Health, Labor dan Welfare mencatat pada tahun 2016 terdapat 1.083.769 tenaga kerja asing yang berada di Jepang, jumlah tersebut meningkat 175.873 orang jika dibandingkan dengan periode tahun sebelumnya.

Masuknya tenaga kerja asing ke Jepang sebenarnya merupakan bagian dari sejarah yang panjang. Pada awal tahun 1980 an hingga 1990 an, tenaga kerja asing yang datang ke Jepang jumlahnya meningkat drastic, khususnya dari tenaga kerja asal Filiphin, Cina, Brazil, Peru dan beberapa negara lainnya. Sebelum masuknya tenaga 
kerja asing dari berbagai negara tersebut, tenaga kerja asal Korea Selatan dan Cina telah terlebih dahulu masuk dalam pasar tenaga kerja Jepang, hal ini tentu tak dapat lepas dari sejarah kolonialisasi yang dilakukan Jepang kepada Cina dan Korea.

Para tenaga kerja asing yang berada di Jepang umumnya memiliki karakteristik dari sisi jenis pekerjaan yang digeluti. Umumnya, mereka ditempatkan pada sektor pekerjaan 3K ( Kiken, Kitsui , Kitanai ), jenis pekerjaan ini banyak ditemukan pada sektor manufaktur, konstruksi dan lain-lain. Beberapa kendala yang dihadapi oleh para tenaga kerja asing di antara lain adalah adanya keterbatasan kemampuan berkomunikasi, dan sedikitnya pemahaman terkait budaya dan cara berpikir masyarakat Jepang.

Di tengah masalah demografi yang terjadi di Jepang, masuknya pekerja asing menjadi salah satu solusi untuk dapat mengatasi permasalahan kekurangan tenaga kerja. Berdasarkan data yang dikeluarkan oleh Ministry of Health, Labor and Welfare, pada tahun 2016 mayoritas tenaga kerja asing yang berada di Jepang berasal dari Cina, disusul pada urutan berikutnya adalah tenaga kerja asing dari Vietnam, Filiphin, Brazil dan Nepal. Dari perkembangan masuknya tenaga kerja asing tersebut, yang menarik adalah terdapat kenaikan yang sangat signifikan dari tenaga kerja asal Vietnam yang jumlahnya mengalami kenaikan $56,4 \%$ pada tahun 2016 jika dibandingkan dengan tahun sebelumnya. Di tengah kebutuhan Jepang terhadap tenaga kerja asing untuk mengisi beberapa sektor industri mereka, tak menutup kemungkinan bahwa dengan semakin tingginya migrasi manusia akan menciptakan masyarakat Jepang menjadi semakin majemuk.

\section{Kesimpulan}

Konsepsi Jepang sebagai negara dengan masyarakat yang homogen nampaknya tidak lagi sesuai pada situasi saat ini. Hal ini dapat terlihat dari sejumlah fakta yang menepis anggapan terkait konsepsi homogenitas masyarakat Jepang. Hal tersebut ditunjukkan dengan keberadaan kelompok minoritas yang berada dan telah menetap di Jepang seperti Burakumin, Ainu, Zainichi Korea dan kelompok pekerja asing. Sejumlah kelompok minoritas tersebut tak jarang menghadapi permasalahan khususnya terkait praktek diskriminasi dan tantangan dalam kehidupan sehari-hari.

Globalisasi memungkinkan terjadinya perpindahan manusia dari satu tempat ke tempat lainnya dengan berbagai factor pendorong. Dalam beberapa tahun terakhir, Jepang dihadapkan pada sebuah permasalahan yang cukup serius terkait populasi yang terus mengalami penurunan. Hal tersebut dapat berimbas pada kekurangan jumlah Angkatan kerja yang seharusnya dapat mengisi kebutuhan sektor tenaga kerja di berbagai sektor industry. Sebagai negara yang memiliki potensi di sektor industri, salah satu yang dilakukan oleh Jepang adalah mendatangkan sejumlah tenaga kerja asing. Dengan semakin terbukanya Jepang terhadap luar, maka hal ini dapat menjadikan Jepang sebagai bangsa yang multicultural.

\section{Referensi}

Burgess, Chriss. 2004. Maintaining Identities. http://www.japanesestudies.org.uk

Burgess, John. (1986). Japan Proud of Their Homogeneous Society. https://www.washingtonpost.com/archive/ politics/1986/09/28/japanese-proud-of- 
their-homogeneous-society/629281b9-

3357-4169-80ba-eb5d031f1c31/ diakses pada 23 september 2021

Denoon, Donald (ed). (2001). Multicultural Japan Paleolithic to Postmodern. United States of America : Cambridge University Press

Elsy, Putri. (2018). Fenomena Tenaga Kerja Asing di Jepang Dewasa Ini. Outlook Japan : Journal of Japanese Area Studies Vol.6 No.1 Juni 2018

Hariyadi, Edi. ( 2012 ). Homogenitas Versus Multikulturalisme : Perdebatan Penerimaan Pekerja Asing di Jepang. Thaqafiyyat. Vol 13 No 2. http://202.0.92.5/adab/thaqafiyyat/article/vi ew/80/70 diakses pada 23 september 2021

Kazufumi, Manabe dan Harumi Befu. (1993). Japanese Cultural Identity. https://doi.org/10.1080/09386491.1993.11 $\underline{827036}$

Kuwahara, Yasuo. (2005). Migrant Workers In The Post-War History of Japan. Japan Labor Review https://www.jil.go.jp/english/JLR/documen ts/2005/JLR08_kuwahara.pdf

Lie, John. (2001). Multiethnic Japan. United States of America : Harvard University Press

Sugimoto, Yoshio. (2003). An Introduction to Japanese Society. Cambridge University Press

Salsabila, Alvi Aniqo Nuri. (2021). Identitas Biracial Jepang Dalam Film Hafu : The Mixed-Race Experience In Japan. Skripsi, Universitas Airlangga
Sugiyono. 2012. Metode Penelitian Kuantitatif Kualitatif dan R\&D. Bandung : Alfabeta.

Weiner, Michael. (1997). Japan's Minorities The Illusion of homogeneity second edition. Routledge : New York

https://www.bbc.com/news/world-asia$\underline{34615972}$ diakses pada 23 September 2021

Ministry of Health, Labour, Welfare. 「外 国人雇用状況」の届出状況. https://www.mhlw.go.jp/file/04Houdouhappyou-11655000Shokugyouanteikyokuhakenyukiroudoutais akubuGaikokujinkoyoutaisakuka/6424474.pdf 